\title{
OUT-OF-SCHOOL SUSPENSIONS: COUNTER-NARRATIVES FROM THE STUDENT PERSPECTIVE
}

\author{
Karen McEIrath ${ }^{1}$ \\ Fayetteville State University \\ Lori Guevara \\ Fayetteville State University \\ Zahra Shekarkhar \\ Fayetteville State University \\ Joe M. Brown \\ Fayetteville State University
}

\begin{abstract}
Out-of-school suspension (OSS) is a major disciplinary tool that has impacted large numbers of students in the United States. Most research into OSS has drawn exclusively on data collected from school records and other "official" sources, and this body of work has contributed to our understanding of suspension decisions by school officials. Considerably less is known about how students experience out-of-school suspensions. This line of inquiry is important because it captures the student voice and reveals a series of counter-narratives that offer alternative interpretations of students' behaviors that lead to OSS. The aims of this study were twofold: 1) to explore the backgrounds and contexts of the behaviors for which students were suspended, and 2) to examine the degree to which suspension practices reflected criminal justice processes. Data were collected from semi-structured interviews with 26 students who had experienced at least one OSS during the previous 18 months. Collectively, they had been suspended from 10 different public high schools in one county. The sample was largely African American and male.

Respondents provide important contextual details about the events as they describe their role, frustration over subjective infractions, labeling, and concerns about limited due process.
\end{abstract}

Keywords: school suspension, school discipline, zero tolerance

\footnotetext{
${ }^{1}$ Acknowledgement: We are grateful to the youth and young adults who participated in this study. Thank you for sharing your stories. Correspondence to: Karen McElrath, Department of Criminal Justice, Fayetteville State University, 1200 Murchison Road, Fayetteville, NC 28301 (email: kmcelra1@uncfsu.edu).
} 


\section{INTRODUCTION}

In the context of formal social control, the monitoring of "dangerous classes" occurs in a range of settings that include but also extend beyond the criminal justice system (Simon, 2007). For example, the hyper-surveillance of people has expanded or diffused to the domains of child protection (Edwards, 2016; Wrennall, 2010), drug treatment (McElrath, 2018), homeless interventions (Johnsen, Fitzpatrick, \& Watts, 2018), and public schools in the US (Wacquant, 2001). Although formal social control mechanisms have long been embedded in public schools, both the nature and range of disciplinary outcomes in schools have become increasingly more stringent over the last several decades (Skiba, Arredondo, \& Williams, 2014a). In particular, out-of-school suspension (OSS) has emerged as a major disciplinary tool.

The proportion of students who have experienced out-of-school suspensions in the US is striking. Approximately 2.7 million public school students experienced one or more out-ofschool suspensions during the academic year 2015-2016 (Office for Civil Rights, 2018). This figure represents about $5.5 \%$ of students who were enrolled in public schools in that year. Statelevel estimates are also telling. In an extensive longitudinal study, Fabelo and colleagues (2011) examined records of all 7th graders who were enrolled in Texas public schools during a threeyear period and followed them for six years. Between the 7 th and 12 th grades, $31 \%$ of students had experienced at least one out-of-school suspension, and over half (54\%) had received an inschool suspension. The authors also found that multiple suspensions were common among students who had been suspended ( $\bar{x}=8$ suspensions or expulsions over six years).

Youth who are suspended from schools are susceptible to or directly experience a host of consequences, including being held back or required to repeat a grade (Fabelo et al., 2011), loss of instructional time (Losen, Sun, \& Keith, 2017), extended disconnectedness with schools (Brown, 2011), lower academic achievement (Morris \& Perry, 2016; Noltemeyer, Ward, \& Mcloughlin, 2015), and higher probability of dropping out of school (Peguero, Bondy, \& Shekarkhar, 2016; Noltemeyer, Ward, \& Mcloughlin, 2015).

\section{RESEARCH ON RACE-BASED DISPARITIES AND SCHOOL SUSPENSIONS}

Evidence of racial disproportionality in school suspensions has existed for more than four decades. To illustrate, suspension data from the 1972-73 school year were submitted by 2,862 school districts to the federal Office of Civil Rights. Analyses of these data by the Children's Defense Fund (1975) found that suspension rates were twice as high for Black students compared to students in all other racial/ethnic groups. Among students in secondary schools, Blacks were three times more likely than whites to have been suspended from school $(12.8 \%$, 4.1\%) (Children's Defense Fund, 1975).

Among students enrolled in grades 6 through 12, national data from 1993 reveal that the suspension rate for African American males (42\%) was more than twice the rate for nonHispanic white males $(16 \%)$ and approximately double the rate for Hispanic males $(22 \%)$ (National Center for Education Statistics, 2016). Similar patterns were observed in 2012 when $48 \%$ of African American males enrolled in grades 6 through 12 had been suspended, more than double the rate for white non-Hispanic (21\%) and Hispanic males (23\%) (National Center for Education Statistics, 2016). Race-based disparities have also been reported for female students. Data from 2012 show that 29\% of African American females enrolled in grades 6 through 12 had 
been suspended, compared to $9 \%$ of white non-Hispanic females and $12 \%$ of Hispanic females (National Center for Education Statistics, 2016).

Compared to whites, African Americans are significantly more likely to be referred for discipline or discretionary actions (Anyon, Jenson, Altschul, Farrar, McQueen, Greer, Downing, \& Simmons, 2014; Fabelo et al., 2011; Gregory \& Weinstein, 2008; Rocque, 2010), and suspended or expelled from school (Anyon et al., 2014; Huang \& Cornell, 2017) even when controlling for socioeconomic background and other factors (Morris \& Perry, 2016).

Race/gender dynamics have revealed mixed results. Although some studies have found that African American males are suspended at higher rates than other race/gender groups (Skiba et al., 2002), race disparities among female students have also been documented (Annamma et al., 2019). For instance, Blake and Butler (2011) found that African American females were twice as likely to be suspended compared to Latina and white non-Latina females and that infraction categories differed across race/ethnic backgrounds. In that study, African American females were often suspended for behaviors that deviated from "traditional standards of femininity" (Blake \& Butler, 2011, p. 100).

Rates of misbehavior are approximately the same for African American and white students (Huang, 2016; Skiba et al., 2002) and race disparities associated with suspensions are not explained fully by the types of infractions or the reasons for disciplinary action (Anyon et al., 2014; Huang \& Cornell, 2017; Nicholson-Crotty, Birchmeier, \& Valentine, 2009; Skiba et al., 2002). Although one study found that past problem behavior was linked to suspensions among African Americans in the $8^{\text {th }}$ grade (Wright, Morgan, Coyne, Beaver, \& Barnes, 2014), that study was limited by its measurement of problem behavior. The measure incorporated teachers' reports of problem behaviors noted in kindergarten, first, and third grade. Some evidence suggests that African American male children often display gendered behaviors that are culturally valued within their communities but can be interpreted differently by teachers (Wood $\&$ Harris, 2016). Conflict can arise between teachers and African American male students when the former misinterpret cultural behaviors as inappropriate. This conflict can reduce the potential for "closeness" between teachers and students, which is deemed to be important for learning (Wood, Essien, \& Blevins, 2017). Critical race theorists have challenged majoritarian perspectives and their impact in the classroom:

....as a result of racial incongruence and the over-reliance on dominant discourses regarding black males, teachers regularly perceive their black male students as deviant, and interpret black male behaviors as overly aggressive, disrespectful, defiant, and intimidating, even if the intent of these behaviors is just the opposite (Allen \& WhiteSmith, 2014, p. 448).

Structural factors also have been linked to race-based disparities and school suspensions. For example, some studies have shown that suspension rates are highest in schools with large proportions of African American and/or Latina/o students (Anyon et al., 2014; Welch \& Payne, 2012). However, suspension disparities that disadvantage African American students have also been observed in schools with small percentages of African American students (Gregory, Cornell, \& Fan, 2011). 


\section{RESEARCH ON SCHOOL DISCIPLINE AND CRIMINAL JUSTICE}

The increasing frequency of OSS has occurred alongside the expansion of punitive policies in the criminal justice system, e.g., mandatory minimum sentencing (Schlesinger, 2011; United States Sentencing Commission, 2017), pretrial detention (Cohen, 2013; Wiseman, 2014), excessive bail and fees (Gleicher \& Delong, 2018; Rabuy \& Kopf, 2016). Indeed, the parallels between school suspensions and criminal justice policies are noteworthy. Both domains function as tools of exclusion that work to separate individuals from their social worlds and reinforce spoiled identities. Moreover, similar to the disproportionate number of people under criminal justice control who have been convicted of non-violent offenses (Kaeble, 2018), youth tend to be suspended from school for relatively "minor to moderate" acts of deviance (Skiba, Arredondo, \& Williams, 2014a, p. 550), during which students are perceived to be disruptive, defiant, or insubordinate (Skiba, Chung, Trachok, Baker, Sheya, \& Hughes, 2014b). Scholars have argued that racial disparities in suspension decisions are particularly pronounced for certain types of infractions, namely loosely-defined misconduct (e.g., insubordination, defiance) that is especially prone to misinterpretation by school officials (Irby, 2014; Skiba et al., 2002). These events have been described as "subjective infractions" (Irby, 2014, p. 518) that occur during "interactive dayto-day disruptions" (Skiba et al., 2014b, p. 641). In one of the nation's largest school districts, fewer than $2 \%$ of out-of-school suspensions in one academic year resulted from violations of weapon, drug, or alcohol policies. In contrast, $46 \%$ of suspensions were due to insubordination, disruption, noncompliance, or disrespect (Raffaele Mendez \& Knoff, 2003). In Colorado, 86\% of suspensions resulted from four types of infractions: detrimental behavior, disobedience, defiance, and other (non-criminal) code-of-conduct violations (Pfleger \& Wiley, 2012). Much like the double-edged sword of discretion that is available to police officers who can opt to charge individuals only with the broad-based offense of "resisting arrest" (Holmes, 2017), insubordination and other disruption-like infractions are most prone to subjective interpretation by school-based rule enforcers (Irby, 2014). Moreover, these infractions disproportionately affect students of color (Huang \& Cornell, 2017).

Scholars have highlighted the parallels between contemporary school settings and criminal justice contexts. For instance, schools have implemented types of surveillance that replicate those in criminal justice contexts. School-based surveillance strategies include extensive use of security cameras (Warnick, 2007), metal detectors (Hankin, Hertz, \& Simon, 2011) and searches of students or their possessions (Nance, 2013). Moreover, the frequent presence of police and security personnel in US public schools has worked to enhance links between schools and criminal justice. A national study of approximately 1,600 public schools in the US found that 46,290 school resource officers, other police officers, or security personnel worked full-time in 24\% of public schools during 2013-2014 (Gray, Lewis, \& Ralph, 2015). Another 36,110 police or security personnel worked part-time in 19\% of schools. Most of these police or security personnel were based in high schools with large numbers of students and in schools that had lower proportions of white non-Hispanic students (Gray et al., 2015). Schools located in African American "hyperghettos" have been described in terms of their "carceral atmosphere" where "custody and control" have taken precedence over learning (Wacquant, 2001, p. 108).

"Zero tolerance" is another link between the criminal justice system and school discipline. The phrase purportedly emerged from the Reagan Administration during the early era of the War on Drugs (Newburn \& Jones, 2007). Beginning in the 1980s, zero tolerance 
embraced a host of strategies that targeted individuals who used, dealt, supplied, or trafficked illegal drugs. The concept expanded to include "zero tolerance policing," a crime control practice that greatly defined law enforcement in New York City beginning in the 1990s (Manning, 2001; Newburn \& Jones, 2007). Among other tactics, zero tolerance policing included "crackdowns" on "low-level incivilities" (Newburn \& Jones, 2007, p. 226) and other behaviors that were visible to the authoritarian gaze. Following a number of school shootings in the US, zero tolerance policies crept into school environments (Casella, 2006; Raufu, 2017), and over the last several years have been a main driver of increasing suspensions and other forms of school discipline. The ideology behind zero tolerance no doubt diffused from criminal justice to public schools and other domains.

Another link between school suspensions and criminal justice is the school-to-prison pipeline whereby school suspensions and expulsions are believed to be associated with or lead to arrests and prosecutions in the criminal justice system (Skiba et al., 2014a). According to Rocque and Snellings (2018), this body of work has conceptualized the link in different ways. One approach argues that students who are suspended or expelled from schools are more likely to have their cases referred for juvenile or criminal justice processing. Indeed, overlapping sanctions might result from the greater presence of police in public schools who are in a position to facilitate referrals to the juvenile and criminal justice systems. Additionally, students who are suspended out-of-school might experience more freedom to engage in offending or feel disconnected from school and their social worlds within school settings. Research has found that students who are suspended are more likely to come into contact with the juvenile justice system (Fabelo et al., 2011). Moreover, the likelihood of arrest has been found to increase for youth who are suspended relative to those who are not suspended (Mowen \& Brent, 2016), and suspensions that occur over multiple years further increase the probability of arrest (Mowen \& Brent, 2016). Welch (2018) argues that although risk management has emerged as an important strategy of social control in school settings, it interacts with perceptions of minority threat to produce disparate suspension rates between African American and white students.

Focusing on 53 counties in Missouri over two years, Nicholson-Crotty, Birchmeier, and Valentine (2009) examined the relationship between Black/white disproportion in OSS with Black/white disproportion in referrals to the juvenile justice system. In one stage of their analysis, the authors found that Blacks were more likely than whites to be suspended in 5 of 6 infraction categories (e.g., $95 \%$ of Blacks were suspended after being "charged" with weapon infractions, compared to $85 \%$ of whites). Additionally, the authors used multivariate analysis and found that the relative rate of Black/white OSS significantly increased the relative rate of referrals for Black youth to juvenile justice, particularly in urban areas. This study documented important aggregate links in disproportionate minority contact across the two institutional contexts, i.e., education and juvenile justice.

\section{AIMS OF THE STUDY}

Previous research discussed above has highlighted patterns and trends of school suspensions and suggests an ever-expanding "school discipline net of social control" (Irby, 2014, p. 514). Out-of-school suspensions have increased substantially over the last several years (Skiba et al., 2014a) and have disproportionately resulted from behaviors that are subjectively interpreted as defiance, insubordination, and the like (Irby, 2014; Phleger \& Wiley, 2002; Skiba et al., 2014a, 2014b). Previous studies have also contributed to knowledge by exploring 
contextual similarities between school discipline and criminal justice, particularly as they relate to systems that reinforce race disparities. Collectively, the previous work has drawn largely on data gleaned from school records or data collected from school officials (e.g., teachers and principals). These data reflect the positions or actions of those in power within the school. Although these studies have increased our understanding of the processes and outcomes of school suspensions, the data on which they are drawn reflect official perceptions of students' behaviors while ignoring the student voice (Huang \& Cornell, 2017). Much like "official records" that relate to the criminal justice system (e.g., arrest and conviction data), school records tend to ignore the voice of individuals who are accused of some behavior, processed in a system, and subsequently punished. Instead, school records represent the official version of events that capture decision-making among those in power. The over-reliance on school records, in particular for understanding the processes of school discipline, means that we know significantly less about school suspensions from youth who have experienced them.

In the present study, we focus on the student voice in an attempt to capture students' experiences with out-of-school suspensions. Through semi-structured interviews with marginalized youth who have been suspended from school, we explore their counter-stories (Allen \& White-Smith, 2014) that serve to unpack and challenge majoritarian narratives of school discipline. Given the contextual similarities between school discipline and criminal justice that we highlighted in the previous section (see also, Mowen \& Brent, 2016; Rocquet \& Snellings, 2018), we are also interested in exploring students' counter-stories to compare the mechanisms of social control that might shape and define school discipline as it relates to criminal justice. We address the following research questions from the student perspective: 1) What are the backgrounds and contexts of the behaviors for which students were suspended? 2) To what extent do suspension practices reflect criminal justice processes?

\section{METHODS}

Data collection occurred over 14 months beginning in 2016. Semi-structured interviews were conducted with individuals aged 16-21 who had been suspended out of school at least one time during their high school years (i.e., grades 9-12). The interviews lasted between one and two hours. Twenty-three of the 26 interviews were audio-recorded. Three others were not recorded after these individuals arrived unexpectedly for an interview after hearing about the study from other respondents. The interviewer had no immediate access to audio recording equipment because these three interviews were unplanned. Rather than rescheduling the interviews and risk losing potential study participants, the researcher conducted the three interviews and took detailed notes of interviewees' responses.

Interview topics focused on students' perspectives about the suspension experience(s), the types of punishments imposed, the extent of due process, the impact on academic work, and their relationships with teachers and school resource officers. Respondents were also asked about their plans/goals, whether they had been involved with the juvenile and criminal justice systems, and related issues. Youth who had been suspended more than once were asked to describe the first and most recent suspension and the events that led to the suspensions. Interviews were conducted by the first author $(n=20)$ and by an undergraduate student of Hispanic descent who had recently graduated from college and was trained in interviewing skills and research ethics $(n=6)$. The first author transcribed all interview data. 
Interviews were held in places that were convenient to the respondent, a conscious decision on the part of the researchers in an attempt to shift some of the power imbalance to the respondent. These interview settings included private residences, quiet sections of fast-food restaurants, picnic tables in public parks, and a university office. Each participant provided informed consent, and parental consent was also obtained for respondents who were aged 16-17 years old. Personal identifiers were not part of data collection; respondents were promised anonymity and confidentiality. Each respondent was compensated with a $\$ 25$ gift card for their time and travel to/from the interview. The university's Institutional Review Board approved the study protocol.

A total of 26 study participants were recruited through various outreach strategies, including word of mouth, fliers placed in settings that were frequented by youth, and social media. Additionally, five of the 26 participants were recruited through chain referrals. Although we attempted to recruit youth from various sociodemographic backgrounds, our final sample consisted mainly of adolescents or young adults who identified solely as African American (22 of 26). Two white non-Hispanic youth participated in the study, and two other respondents selfidentified as African American and white non-Hispanic. Our sample was comprised primarily of males $(65 \% ; n=17)$. We focused on youth who had been suspended from public high schools in one county in North Carolina, excluding students who were enrolled in one of ten small private schools with strong religious affiliations (largely Protestant). At the time of the study, 17 public high schools were operating in the county, including two classical high schools, one alternative high school, one health/science specialty high school, and two early college high schools. Collectively, the 26 participants had been suspended from ten public high schools in the county, although the most recent school that they had attended was not necessarily the school where they had experienced suspension. The study was conducted in a metropolitan statistical area with a county population of 327,127 in 2016. At the time of the study, African Americans accounted for $45 \%$ of the student population enrolled in public schools in the county (whites $=31 \%$ ).

\section{Analytical Strategy}

Our analytical strategy was guided by thematic analysis. We followed the guidelines developed by Braun and Clarke (2006), who outlined six phases of thematic analysis. First, we immersed ourselves in the data by reviewing the transcripts multiple times prior to coding. The first author transcribed all interviews, and the transcription process itself helped to gain a strong familiarity with the data. Second, we developed the initial coding using an inductive approach that was driven by the interview data. Some data extracts were coded into more than one potential theme. Other data extracts were coded as possible outliers, whereby events, behaviors, and experiences appeared to depart from dominant patterns. Although one member of the research team led the coding stage, transcribed interviews were distributed to other members of the research team during the data collection stage.

The third phase involved the identification of themes. We placed the coded data extracts under themes and, in some instances, sub-themes, conscious that the importance of our themes should not be determined by the frequency of data extracts that support the themes (Braun \& Clarke, 2006). In Phase 4, we reviewed our themes and observed that some of our themes or sub-themes were similar to selected processes and concepts that characterize the criminal justice system and in some instances, criminological frameworks. These observations were no doubt influenced by our disciplinary expertise: all co-authors have doctoral training in the fields of 
criminal justice and/or criminology. In the fourth phase, co-authors KM and ZS returned to the original interview data to ascertain whether additional data extracts might fit as part of a pattern or an outlier within these emerging themes or sub-themes. We first reviewed the original data separately. Then we met to discuss the codes and categories of text segments that related to criminal justice processes. These discussions led to important insights about the links between school discipline and criminal justice that might have been overlooked, given the reliance on "coding solo" (Saldaña, 2010). Thus, our coding and thematic analyses commenced with an inductive data-driven method and later incorporated a deductive approach as we returned to the data to check for additional extracts that reflected criminal justice speak. We also refined themes, e.g., combining some themes, discarding other themes that had little data to support the salience of the theme.

In Phase 5, we further refined the themes to "describe the scope and content of each theme in a couple of sentences" (Braun \& Clarke, 2006, p. 95). The last phase involved the write-up, which integrated our analytical narratives with the interview data in order to provide a story that reflects meaning and depth.

We sought to validate our interpretation of some interview data. In the early stages of data collection, for example, a respondent described restrictions in due process at the suspension hearing that seemed to be inconsistent with the procedures outlined by the State. The researcher/interviewer then explored this phenomenon in subsequent interviews, yet without mentioning the particular aspect of the hearing process. Instead, subtle probes were used. Other respondents then validated the earlier report. In a second example, a few respondents described a condition at the local alternative school that we initially perceived to be misguided. We explored the report in several other interviews and found a consistent pattern, although one that might be explained as "urban folklore." In other instances, we asked respondents to clarify experiences about which we were unclear. Finally, we often returned to lines of inquiry as the interview progressed, which helped solidify interpretations of the data.

\section{FINDINGS}

All 26 respondents had experienced out-of-school suspensions within the 18 months preceding the interview. Multiple in- and out-of-school suspensions were the norm; four of the 26 participants had been suspended one time only. Six others had been suspended on seven or more occasions, including two youth who had been suspended 13 times. Most participants recalled the first time that they were suspended. Among this group, 11 had experienced their first suspension while attending middle school (i.e., grades 5-8), and three others recalled having been suspended in elementary school.

We asked respondents to describe their first and their most recent OSS, and in most instances, we asked them to discuss each OSS (names attached to respondents' quotes are fictitious). We asked students about the reasons for their out-of-school suspensions. A few students had been suspended for fighting or for attempting to break up fights, however, these events were rare among respondents and generally occurred when students were younger, e.g., while attending middle school or in the ninth grade during the first year of transition to high school. Respondents who had been suspended for fighting tended to acknowledge their role in the altercation. The vast majority of suspensions, however, resulted from non-violent behaviors, notably minor acts of deviance that violated school rules. In this section, we discuss the main reasons for which students had received OSS, as described by respondents. OSS largely resulted 
from official perceptions of insubordination, leaving school without permission or tardiness, inappropriate clothing, and beliefs by school officials that students had used marijuana before entering the school building.

\section{Main Reasons for OSS}

Insubordination. Within the county school district, "insubordination" was broadly defined as the refusal to comply with requests from school personnel. The behavior was designated as a Class I violation - the least serious of all infractions. Consistent with previous studies, the data suggest that "insubordination" encompassed a range of behaviors that often centered on perceptions of disrespect or poor demeanor. Insubordination included talking back to or questioning school officials, sleeping in class, placing one's head on the desk in a resting position, and other behaviors that were perceived as disrespectful. Much like the sweeping and subjective offense of disorderly conduct that can lead to arrest (Theriot, 2009), "insubordination" in school settings served as a catch-all category for behaviors or attitudes that appeared to challenge the authority of a teacher or other school personnel. Some students were very aware of the over-reach of the infraction for which students could be suspended:

I: So, in 9th grade, you were suspended for...

R: Insubordination.

I: But what does that mean to the school?

$\mathrm{R}$ : Could be anything. Could be talking back or you not listening to the way that they want you to do something. Like they have rules that say you can only go to the bathroom so many times...I had a situation where a teacher wouldn't let me go to the bathroom. My mom always told me, "If you have to go to the bathroom, you get up and walk out the door and go to the bathroom. You don't do it abruptly, you don't make a scene, but you go." I got suspended for that probably two or three times. They wouldn't let me go to the bathroom. And I wasn't going to sit there and not go to the bathroom. So insubordination could be this and that. (Adrienne, age 20, suspended on at least 10 occasions)

Similar to criminal justice practices in which one arrest can incorporate multiple charges, suspensions often resulted from several different infractions that emerged from the same event. For example, students who were suspended for insubordination were often cited for the infraction of "disrespect" or "disruption." Indeed, at times it became difficult for the interviewer to delineate between these categories. Some students voiced their frustration over what they perceived to be a process that lacked transparency:

....and one offense leads to another. Like you could do one thing, and then it gets labeled as three things. Like it could be disrupting class, and then there's something else and something else. But you never know what the other two was for, you only know about the disrupting class. But on the write up, it says multiple things that you did...And then they get you to write statements and they'll mix up your statements. Like they don't read it to the full extent. (Shamar, age 20) 
Brandon, a 16-year old African American male suspended one time only, used criminal justice speak (i.e., "charges") to describe the violations of school code for which he was suspended. He voiced frustration because it was not clear to him why he was "charged" with certain infractions:

Yeah, they charged me with a lot of things. Assault, and I was walking away trying to calm down and my friend was trying to calm me down. And they also charged me with insubordination because I was walking away trying to calm down. So she charged me for assault, insubordination, disruption. I don't even know where the disruption came from.

In general, students did not deny their behaviors, but often suggested counter explanations for their actions:

Well sometimes they'd [teachers] just catch an attitude. I'd put my head down on a desk. I'd be paying attention to the teacher, I really was paying attention but I didn't feel good. She got into it with me, started saying to sit up and all that. I just wasn't well. She sent me to the office and I got OSS for that. (Justin, age 18, suspended 4-5 times in middle school and numerous times in high school)

In one instance, insubordination or disrespect shaped how a student responded to school personnel when learning about the punishment. Donovan, age 17, had been suspended out of school on six different occasions during the year of the interview. He was frustrated because of repeated out-of-school suspensions despite behaviors that he did not view as serious:

R: And every time I've got suspended it's been for little stuff.

I: Give us some examples.

R: Like inappropriate behavior, disruptive behavior. I got it one time for skipping. Truancy. They don't ever offer me nothing else. And I feel like there's other kids they offer ISS, but I've never got offered ISS. It's always like "You going home for two days."

I: Are you dealing with the same personnel, the same authority figure?

R: Every time I've got in trouble, I get suspended. I've met with each principal all of them suspend me.

I: What do you think that's about?

R: I don't know to be honest. I guess it's because I come off as like "OK, if you're going to suspend me, then just suspend me. Get to it." And I don't think they like that.

I: They would want you to act like how do you think?

R: You know like [says dramatically], “Oh no, don't suspend me!” I can't do that. If you're going to suspend me, then just do it and I'll get the days over with.

Some students recalled that the severity of the punishment increased when they further challenged school personnel who they felt misunderstood events:

I was suspended a couple of times, same teacher each time. She was upset with the other students in the group. You see it was spirit week. And the club was optional. 
It was supposed to be optional. But the teacher said I was skipping. So I got detention. I asked a lot of questions. I challenged her. Not in a mean way, but I wasn't sure why she was giving me detention. Then she said my attitude was disrespectful and I got two days OSS. (Briana, age 17)

I got suspended last year. The lady felt like I was not respecting her authority. She works for the school. We were in the lunchroom and she was yelling at a student. I mean she was yelling! But she misinterpreted the whole thing, the whole event. I went to tell her about it. I wanted to tell her what had really happened. Later I was told, "Maybe you should have approached her differently." Anyway, she started yelling at me, she got real defensive. And I was only trying to tell her what really happened with this other person. I was not trying to argue with her. She kept yelling down at myself and I'm not sure why I was intimidating her. She made it sound like I was disrespecting her. I got two days OSS. I said please check the camera because I knew they would see that I tried to get super non-violent. I've taken speech and debate and she could tell I was educated. (Jasmine, age 17)

Unexcused Absences. A few students reported being suspended for truancy or chronic tardiness. Others had attended school but left briefly without permission. Some of these behaviors were motivated by a desire to buy lunch in nearby fast-food restaurants. Instead of using the cafeteria at lunchtime, a few students reported that they quietly left the school, purchased their lunch off-site, and then attempted to re-enter the school building discreetly. They were aware that having food in a bag with a restaurant logo was grounds for punishment, even when they were not observed leaving or re-entering the school. Tonya, an 18-year-old African American student, had left school and returned with lunch purchased elsewhere. The situation escalated when a teacher confronted the student:

I: So when were you last suspended?

R: Just last Thursday. And I know they are sending me to [alternative school] when I get back.

I: So what happened on Thursday?

R: I went to get me Chinese food. They saw me coming back in, I did come back so it's not like I was skipping. It was lunchtime. And she [teacher] started yelling at me, and I cussed at her. And the assistant principal he started yelling at me too. The two of them, just embarrassing me.

I: Where were you when they were yelling?

R: In the hallway right by the cafeteria. Everyone was there and they just were yelling at me asking me why was I skipping, where I went, that kind of thing. She was embarrassing me in front of people, and that's why I cussed them out. They know me. They know I have anger problems. Why they set me up like that? They knew how I was going to react to all that.

I: So they knew that you had left the building for lunch and knew you came back. What would have been the best way for them to talk to you about leaving the building? 
R: Well alright we're not supposed to leave the building. But lots of kids do leave. But like you said, why couldn't they just talk to me? Why they have to yell? They know what I would do with that.

I: So you were suspended - OSS? How many days?

R: Three days, yea. Out of school. But I know they will send me to [alternative school].

Malik, age 18, had also been suspended for leaving and returning to school after he had bought lunch at a local business. He explained that students' decisions to leave school to purchase lunch are sometimes motivated by the poor quality of food or limited access to food in the school cafeteria:

R: Lots of people leave at lunch to get something to eat. And they do come back [to school]. You see the food inside the school? It's terrible food and there's not enough of it. Not enough food for all them and if you're on late lunch there's really not enough. People are not leaving the school at lunch because they want to skip. Look at them. They come back. And they come back with food. That's why I got suspended last year. I went out to get food and they saw me [inside the school] with the food. They saw the bag of it. You know the [fast food restaurant] right by [school name]? You can leave the school, go to [restaurant] and be back at the school in 15 minutes.

I: Would students leave at lunch to go out for a cigarette or something too?

R: Maybe, but it's mostly food. I was suspended for that last year.

I: You got out of school suspension?

R: Three days.

Courtney, 18 years old, had been suspended approximately ten times, although none of the suspensions had occurred while enrolled in her current school. Her experience revealed the discretion that some school officials exercised and also suggested that zero tolerance policies probably varied across schools:

One time I could of got in trouble but didn't. I had fourth lunch the longest [latest] lunch, and I snuck out to get Chinese food. I was coming back and jumping over a fence like and the principal caught me. He said, "Are you that hungry? What's wrong with the cafeteria food?" And he said to not do it again and that the next time he'd give me ISS but he just warned me that time. And another time, there was a big fight in my math class and the principal and two assistant principals came up and talked to all of us about it. They found out the girl hit the other girl first and the girl defending herself, she didn't get suspended. Now if that happened in [previous school], they all would have got suspended. Basically, they [officials in the current school] take more time and find out why you're skipping, why you are getting in trouble, why you don't have a note for the bathroom. Those teachers came in early morning and would stay after school.

Dress Code Violations. The school codes prohibited leggings, jeggings, jeans with rips above the knee, sleeveless shirts, and a host of other clothing. Schools often allowed a parent or 
other family member to drop off alternative clothing when students violated the dress code. One student reported that a school counselor gave her replacement clothing that had been in the lost and found for over a year. The student had no family support and would have been sent home if the replacement clothing had not been located. Multiple violations of the dress code could result in out-of-school suspension. Indeed, three students in the sample were suspended for wearing clothing that was deemed to be inappropriate. In one instance, a student's impoverished background helped to explain why she wore clothing that violated the school's dress code:

I: And what happened then?

R: Apparently I violated dress code. I wore skinny jeans and they tried to say they were jeggings.

I: So they're strict with the dress code?

R: Yea.

I: So how many days did they give you in ISS?

R. Two.

I: They didn't give you a warning?

R: They gave me a warning before but I didn't have much clothes so.

I: So when you got suspended for the dress code, did they send you home to change or what did they do?

R: They asked me to call my mom, but we didn't have a vehicle then so she couldn't come to the school. (Monica, age 17)

Marc had been suspended approximately nine times, beginning in the sixth grade. He was sent to alternative school when he was 16, about four months before the interview. Similar to a few females in the sample, Marc appeared to push the boundaries of the dress code somewhat although his clothing in question seemed much more subtle than that reported by other students:

I: And when was the last time you were suspended?

$\mathrm{R}$ : Last year, just before school got out. And I was in the alternative school and they suspended me because of my socks...At [alternative school] you have to wear all black or white socks. And then one day I wore a pair of colored socks. They weren't too bright but I put these black socks over my socks. My socks were showing through the black part and they suspended me for it.

I: Why don't they like different colors of socks?

R: I don't know.

I: I understand that schools have a dress code. And the other schools [names a few high schools], do they have a dress code about socks or is it just [alternative school]?

R: It's just [alternative school]. And when I was at an alternative school [for middle school], we didn't have a dress code about socks.

I: So did you like these socks and you just wanted to wear them? Did you just get tired of that kind of rule there?

R: Yea. Didn't think they'd suspend me like not even a month before the last day of school. Like suspending me over socks and we had less than a month of school.

I: How long did they suspend you for? 
R: Three to five days.

I: OSS?

R: Yea.

Suspected Use of Marijuana. None of the respondents had been suspended for possessing or distributing banned substances such as alcohol or marijuana. However, four students in the study had been suspended for suspected marijuana use. The school district allows suspensions when school officials detect odors or observe behaviors that they believe are consistent with recent drug/alcohol use. These infractions are Class III violations and in the same category as kidnappings, assaults on school officials, rapes, bomb threats, and a host of other behaviors. Ty, age 20, was in the final semester of his senior year when he was suspended and sent to alternative school for smelling like marijuana. He and his family had moved to the state in his tenth-grade year, and it was the only suspension that he had experienced since then. He was visibly distraught as he described the incident that had occurred about one year prior to the interview. Although Ty stayed on track and graduated from high school, he believed that the forced transfer to alternative school led to a college withdrawing its scholarship offer:

R: My mom had dropped me off at McDonald's just before school. Wanted something to eat. Went next door and bought a Black. Smoked it or most of it and walked into school.

I: So it was a Black not a blunt?

R: It wasn't a blunt. Definitely a Black, a Black and Mild [thin cigar containing pipe tobacco]. I smoked most of it and put the rest, about this much [shows the interviewer] in my bag. My teacher said I smelled like marijuana. I said I hadn't smoked marijuana but smoked a Black before school. She said, "Then go to the restroom and wash or clean up so you don't smell like it." So I went to the bathroom, washed up good, cleaned up, thought I had redeemed myself with her. Got back to the class and the principal and assistant principal were there in the class. And the resource officer was there too. The AP [assistant principal] searched my bag. They all searched my bag. Had my bag searched three different times. They searched my bag, my pants, my basketball shorts. They found the rest of that Black and I thought that was a good thing so they'd know I'd been smoking a Black and not marijuana. Nope. They said they were suspending me for smelling like weed. Got 10 days.

I: You got 10 days OSS?

R: Yea, and then I went back. Was there for two days and they said nothing, then they told me they were sending me to [alternative school]. Couldn't believe it. And two days later, they tell me. Going to [alternative school] for smelling like weed. My mom was mad. That was like February of my senior year. I hated it. Hated it so bad. [It] was like jail, the metal detectors, got to get searched, no phones. Teachers didn't care there either. I didn't want to go to alternative school. I wasn't a bad kid. I was a good [athlete], broke two records. Had a scholarship offer. Decent grades. Not a bad child at all. They knew that. Found out two months later that [college] wasn't going to offer me the scholarship anymore because I was in alternative school. Schools don't like that you see. I didn't know I wasn't going to get the scholarship in February when I was sent 
there. Only found out in April. I was so down. I think if I knew in February, I would have given up then, quit school then. It [scholarship offer] meant so much to me. My mom knew it meant so much to me. Just ruined me.

Shamar, age 20, was enrolled in another local high school and was suspended for three days for smelling like marijuana. However, he was not sent to alternative school. Shamar reported having smoked marijuana with his brother while walking to school that morning:

I: OK, you got suspended once during senior year. What was that for?

R: I got suspended for... actually...drugs.

I: Did you have marijuana in your pocket, or...

R: No, I didn't have anything on me. I had just got to school that morning. I had walked to school and me and my brother, we smoked before we got there. And the scent was on our clothes. I made sure I was covered in cologne first and they told me that me and my brother smelled like um, well they didn't actually get my brother - they got me. I was known about the school - my attitude and I only got in trouble once [before that]. I felt like that was kind of unfair.

Lexi, age 18, had just returned to school after she had completed a suspension period in the week before the interview:

I: Why did they tell you they were suspending you?

R: I looked high.

I: What do you mean?

R: My eyes.

I: Were they red or glazed or something?

Friend: Her eyes go low when she's high.

R: You know like your lids get heavy or something?

I: So did they find the weed?

R: Nope. Searched me everywhere. Even searched my shoes. I didn't have any weed on me.

I: Did they say you smelled like weed?

R: Nope. Said I looked like I was high.

I: Does that happen a lot? Students getting suspended for looking like they're high?

R: Not really. But smelling like weed, I've seen that. People get suspended for that.

\section{School Discipline and Criminal Justice}

In this section, we explore two dominant themes that emerged from the data that show how school discipline compares to criminal justice processes. First, we examine how students' past behavior seemed to shape the response of school officials when dealing with subsequent behaviors. We refer to this phenomenon as the power of the "prior record" because it is consistent with criminal justice sanctions that are often increased for individuals who have prior convictions (Jordan \& Freiburger, 2010; Moore \& Padavic, 2010; Rodriguez, 2003). Second, we 
delve into students' perspectives of suspension proceedings and evaluate these processes in terms of due process.

The Power of the "Prior Record." Several respondents perceived that their previous behaviors - no matter how distant in the past - influenced how school officials reacted to them. These youth found it difficult to shake the label of the "bad kid." Justin, age 18, recalled his early childhood when his mother often left him and his younger sibling alone for several hours in hotel rooms. He was later raised by the grandmother of his half-sibling, and he dipped in and out of minor deviance in the neighborhood. Justin was suspended 4-5 times during middle school, usually for truancy. During the interview, he described how his previous behaviors followed him as he transitioned to high school:

I: OK, so that was in middle school. When you got to high school, did you feel like it was kind of like a clean slate? Like you were starting off new in a place where the teachers didn't know you?

R: It wasn't like [that]. See I went to [name of school] middle school and [same name of school] high school. They knew how I was in middle school. And the cop at the high school used to talk to the teachers in the middle school. Nothing changed when I got to the high school. They thought I was a bad kid. And they thought my [younger] brother was too. I had to help him whenever something went wrong. He's my brother. I was constantly getting suspended in high school. A lot of it was hype. Stuff I had nothing to do with. Or I'd get OSS for tardies. A lot of times I'd get suspended, come back to school and get suspended that same week I got back. Even when I got my work done I'd get suspended for stuff.

Other students also reported difficulties as they attempted to resist negative labeling by people in power. One student voiced his frustration over the negative labeling because he believed that he had changed for the better:

I: Why, were you watched more by principals, teachers? Like what do you mean you kept getting suspended more?

R: It's like staff they started to know my name. And once they know your name, they start to watch more. I don't have trouble with teachers no more. The only trouble I have is with administrators - they know my name. Once they know that they can make a situation out of something and blame you.

I: So some people blame you when something is not your fault?

R: Sometimes. And it's because of the "old me" or how I behaved a long time ago. When you try and separate yourself, like act better, it's kind of hard because when you try to separate yourself from your old self, they always pull you back.

I: Is that frustrating?

R: Yes. (Marc, age 16)

I: And you went to [name of high school] from a local middle school?

R: Yes. They treated us the same way they did at the middle school.

I: Tell me about that. 
R: They had similar kinds of people to work at both schools. That was going to be a flag right there. You go from one school to another, the administrators already know you so they think they know your habits. They try and get you out that door. They say they are worried about the suspension rate but they're not. They're worried about the test scores and graduation rate.

I: So the way you improve the graduation rate...

R: Is to kick those [certain kids] out. My class was supposed to be 330 graduating class and we had 270 or something that graduated. And most of them were kicked out or they couldn't graduate because they had too many suspensions. (Adrienne, age 20)

Due Process. A main concern of youth who participated in the study was that suspension decisions and processes often lacked due process. Students voiced concerns that school officials were unwilling to listen to students' explanations of events. The power imbalance that characterizes school structure meant that students had little or no voice during suspension proceedings. The process created great frustration among students:

I: So think back about all those suspensions. Did you tell your side of the story?

R: To lots of people, yea. And some people saw my side of the story, in school. But when you're getting suspended you don't tell it. Well, if you tell it, they don't listen, or they argue about it even though they weren't there. They mix it up. It got to the point I said, "Just give me the days." (Justin, age 18)

I: Is there anything you felt you could have done to reduce the suspensions?

R: I guess if I was more cooperative. I mean I stopped answering their questions. It's frustrating, you answering all their questions and you know that you are still going to get suspended. And you've told your side of the story and they're still going to believe what's on that write-up. They just made you answer all these questions for no reason - just so they could hear you talk. (Donovan, age 17)

Students recalled instances whereby other students had witnessed the event that led to their suspension, but that school officials were unwilling to speak to witnesses:

Why didn't they ask the other students? There were witnesses, the whole class, well at least some of them saw it start. It's kind of like the police body cams. No good at all if they don't use it or if it's turned off. (Evan, age 17)

Other respondents noted that cameras were in place in the area where an incident occurred. These students questioned why school officials did not attempt to review video footage or speak to witnesses that might have exonerated them.

I: Were there any witnesses to that last incident - for the last suspension?

R: Yeah there was and I told them I was not singing that loud and they should talk to the others [other students]. I said, "Are you going to talk with the witnesses?" And he said, "No, 'cause we've got what the teacher said." And I was like, "Why are we even having this conversation if you are just going off what the 
teacher said?" "You obviously don't want to hear my part of the story." I don't see the point. They always do that. Even if you go in there and you have a witness with you... whatever the teacher says, that's what goes man. I don't even fight with them no more.

R: My mom wrote her [the principal] herself. My mom knows I talk things out. She knows I am like that. Not meant to be disrespectful. My mom went to the school. And she said one thing: "Show me the tapes."

I: What did the principal do?

R: She'll side with someone with power. It's just easier for her to side with a teacher. (Jasmine, age 17)

I: Is there anything you would change about the school policy?

R: Yeah. I would change the policy that would give the students the right to tell you something, the right to tell their side of the story. And to look at the cameras. (Brandon, age 16)

Schools in the district are required to hold hearings for students who face OSS unless a student poses an immediate threat to others in the school setting. The extent of due process that is afforded in the hearing depends on the number of days for which a student is suspended. Suspensions of ten days or less are defined as short-term under North Carolina state law. An informal hearing with a principal is required, and students are permitted to offer statements that might mitigate their involvement. However, short-term suspensions cannot be appealed. Nor are they subject to judicial review. Long-term suspensions are those that occur for more than ten days and involve considerably more protections for the student. For example, students who are suspended long-term have the right to record (audio or video) the hearing, question witnesses, and retain private attorneys. Additionally, parents or guardians can contest long-term suspensions. In the present study, the majority of students experienced short-term suspensions. However, several were suspended the day of the event, required to return to school within a few days, report to the principal's office upon their return, and then suspended for an additional ten days. Students voiced frustration with this policy; Shawn, 17, stopped attending the hearings entirely:

I: After you've been suspended for say two days and you have to go back to the school, do you have to bring your mom with you?

R: Sometimes. Every time actually but we stopped going to the hearings because every time I go to the hearings, they suspend me for more days.

I: So the hearing occurs after you've been suspended?

R: Yes ma'am.

I: So you go back to the hearing and they can actually suspend you for more days and send you home that day?

R: Yes ma'am.

\section{DISCUSSION}

Previous research has contributed to our understanding of OSS but has relied greatly on data drawn from school records that reflect the decision-making of school officials. We build on 
the previous work by shifting the focus to the voice of students who have directly experienced suspensions. We addressed two research questions: 1) What are the backgrounds and contexts of the behaviors for which students were suspended? 2) To what extent do suspension practices reflect criminal justice processes? Based on semi-structured interviews with individuals aged 16-21 who had been suspended out-of-school at least one time during the previous 18 months, students' counter-narratives often provided alternative interpretations of the behaviors that led to their suspension, and also served to challenge the dominant discourse of school officials who controlled the suspension process.

\section{Context and Background of Behaviors Targeted for Suspension}

Consistent with findings reported by other scholars (Irby, 2014; Raffaele Mendez \& Knoff, 2003; Skiba et al., 2014a; 2014b), most of the suspensions resulted from infractions that did not appear to be serious. Although slightly more than half the students in the study (14/26) were first suspended in elementary or middle school and several had experienced multiple suspensions, none had been suspended for possession of weapons, drugs, or alcohol. Moreover, very few had been suspended for fighting or other forms of violence. Indeed, the primary infraction that resulted in suspension was "insubordination," a broad ill-defined category that encompassed a host of different behaviors. As Adrienne described, insubordination "could be anything" and in the present study reflected a range of behaviors, including visiting the restroom without permission, sleeping in class, resting one's head on a desk, or verbally questioning a teacher's response. Some students voiced frustration over sanctions that they perceived to be overly punitive given the infraction of "insubordination." Other students were frustrated when multiple and overlapping infractions (e.g., disruption and insubordination) were listed as separate infractions on the same disciplinary report. A few reported that the disciplinary jargon was unclear to them or that their statements appeared to be changed or misinterpreted on the disciplinary reports. Collectively, we were left wondering whether suspensions for these infractions led to any meaningful impacts on behavioral change among these students. Instead, "insubordination" and other broad-based categories (e.g., "disruption") serve to widen the net of school discipline, perhaps in an attempt to deter the more serious acts of deviance, despite the rarity of serious acts (Irby, 2014).

In the present study, several students did not deny their actions that led to suspension; rather, they interpreted their actions differently than the dominant narrative that defined the suspension report. For example, Briana explained how she interpreted a school event as optional but was suspended for an unexcused absence after she questioned the teacher's decision. Malik and Tonya admitted leaving the school without permission but asserted that they did so to buy lunch elsewhere and reiterated that they had indeed returned to school by the next period. Monica acknowledged that she violated the dress code, but also quietly suggested that her impoverished background prevented her from buying additional clothes. Additionally, Monica's mother could not bring a change of clothes to the school because her mother did not own a car. In general, students who participated in the present study might have benefitted had they been afforded the opportunity to be heard in a meaningful way. 


\section{Criminal Justice Processes that are Embedded in School Discipline}

Two themes from the present study contribute to a growing literature that has described links, overlaps, or similarities between school discipline and criminal justice (Mowen \& Brent, 2016; Nance, 2013; Skiba, Arredondo, \& Williams, 2014a; Warnick, 2007). First, some students described suspension decisions that they felt were influenced by their past behaviors including behaviors that they exhibited during middle school that became known to school officials after they enrolled in high school. This situation appeared to occur more often among students who attended middle schools that were located on the same campus as their high school. These students perceived that it was difficult to shake off the deviant labels because the labels had emerged as their master status (Becker, 1963; Hughes, 1945). They felt that labeling contributed to punishment even though some of them asserted that they had changed and matured out of deviance. The salience of past behaviors is consistent with the negative impact of prior record among people, including youth, who are processed by the criminal justice system (Jordan \& Freiburger, 2010; Moore \& Padavic, 2010; Rodriguez, 2003).

Second, students voiced their frustration over suspension proceedings that they felt were characterized by limited due process. In theory, due process is fundamental during criminal justice processing - be it at the arrest, pre-trial, prosecution, or sentencing stage. Students in the present study perceived that the school suspension policies benefitted those in power (school officials) without protecting the rights of the students involved. Students lacked understanding as to why school officials failed to consult witnesses, view video/camera footage, or explore related counter-evidence that might substantiate their innocence. Some described frustration over power imbalances that were tipped in favor of the teacher's interpretation of events. Students sought to challenge majoritarian narratives about their identities but were frustrated because they rarely had the opportunity to do so.

Unbeknown to most of the students, however, is that suspension proceedings must incorporate substantive due process protections only when students are suspended for more than ten days per episode, per North Carolina statute $\S 115 \mathrm{C}-390$. In the current study, most suspensions occurred for ten days or fewer, although some students had experienced dual suspensions that spanned more than ten days when counted collectively in the periods immediately before and just after the hearing. Some students framed the importance of due process by drawing on criminal justice speak; however, the limitations of due process that characterized most suspension processes described in this study were consistent with state regulations. Nevertheless, the students' narratives often reflected bitterness about the process, even when they acknowledged their role in the event. They often returned to school after losing valuable instructional time, aggrieved about the process, and further detached from the school environment.

\section{FINAL THOUGHTS AND STUDY LIMITATIONS}

School discipline is important for maintaining order and facilitating learning. The findings from the present study raise concerns in four areas: 1) the use of broad-based, looselydefined infraction categories that widen the exclusionary net by focusing on minor/moderate deviance, 2) students' behaviors that are at times misinterpreted by school officials, 3) the use of OSS for minor/moderate deviance, and 4) limited due process that is often misunderstood by students. We are encouraged by efforts elsewhere in the US that have introduced changes to 
suspension policies, e.g., limiting OSS to serious offenses such as those that threaten school safety (Vaznis, 2018), introducing non-punitive interventions for addressing minor/moderate deviance (Steinberg \& Lacoe, 2017).

Our findings undergird the need for disciplinary reform. Restorative justice models have been introduced in some schools as an alternative to OSS. Diffused from the criminal justice system, restorative practices in schools have focused on building relationships and community, acknowledging diverse perspectives, repairing harm, and resolving conflict through mediation (Fronius, Darling-Hammond, Persson, Guckenburg, Hurley, \& Petrosino, 2019). Restorative practices appear to contribute to declines in disciplinary referrals and out-of-school suspensions (Anyon et al., 2014), although the degree to which restorative practices can reduce raciallydisparate OSS is inconclusive (Augustine, Engberg, Grimm, Lee, Wang, Christianson, \& Joseph, 2018; Gregory, Huang, Anyon, Greer, \& Downing, 2018). As discussed above, 22 of 26 respondents were African American; thus we were unable to explore Black/white disparities in OSS. Still, discipline teams comprised of various stakeholders (including students) as well as cultural competency training that is meaningful might help to reduce racial disparity in OSS (Fenning \& Rose, 2007). Other scholars have noted that it will take time for the evidence to accumulate before we can determine the efficacy of alternatives to OSS and whether the alternatives have been implemented as intended Gordon, 2018; Steinberg \& Lacoe, 2017).

This study is not without limitations. First, race-based suspension disparities in OSS have been highlighted by several scholars (Anyon et al., 2014; Fabelo et al., 2011; Huang \& Cornell, 2017; Rocque, 2010), yet we were unable to compare suspension experiences among African American, white non-Hispanic, Hispanic and students from other racial/ethnic backgrounds because 22 of 26 study participants identified as African American. Still, we found it interesting that the majority of students who reached out to participate in the study, identified as African American.

Second, most of the interviews (20 of 26) were conducted by a middle-aged white nonHispanic woman who was affiliated with a university; six others were conducted by a Hispanic woman in her early 20 s who had recently graduated from college. Interviews are nearly always framed by power imbalance that favors the interviewer, and the age and professional affiliation of the first interviewer might have reinforced power imbalance in some interview settings. We attempted to shift the power to respondents, e.g., by encouraging them to choose the interview setting, reimbursing them for their time and travel to/from the interview. However, some responses might have been influenced by the power differentials that were difficult to control.

Third, data collected from non-probability samples are not suitable for generalizing to some wider population, nor is that the intention of qualitative methodologies. The extent to which the suspension experiences of students in this study reflect the experiences of other students in the district cannot be determined.

\section{REFERENCES}

Allen, Q., \& White-Smith, K. A. (2014). "Just as bad as prisons": The challenge of dismantling the school-to-prison pipeline through teacher and community education. Equity \& Excellence in Education, 47(4), 445-460. 
Annamma, S. A., Anyon, Y., Joseph, N. M., Farrar, J., Greer, E., Downing, B., \& Simmons, J. (2019). Black girls and school discipline: The complexities of being overrepresented and understudied. Urban Education, 54(2), 211-242.

Anyon, Y., Jenson, J. M., Altschul, I., Farrar, J., McQueen, M., Greer, E., ... Simmons, J. (2014). The persistent effect of race and the promise of alternatives to suspension in school discipline outcomes. Children and Youth Services Review, 44, 379-386.

Augustine, C. H., Engberg, J., Grimm, G. E., Lee, E., Wang, E. L., Christianson, K., \& Joseph, A. A. (2018). Restorative practices help reduce student suspensions. Research Brief. Pittsburgh, PA: Rand Corporation.

Becker, H. S. (1963). Outsiders: Studies in the sociology of deviance. New York: Free Press.

Blake, J. J., \& Butler, B. R. (2011). Unmasking the inequitable discipline experiences of urban Black girls: Implications for urban educational stakeholders. Urban Review, 43(1), 90 106.

Braun, V., \& Clarke. V. (2006). Using thematic analysis in psychology. Qualitative Research in Psychology, 3(2), 77-101.

Brown, T. M. (2007). Lost and turned out: Academic, social, and emotional experiences of students excluded from school. Urban Education, 42(5), 432-455.

Casella, R. (2006). Selling us the fortress: The promotion of techno-security equipment for schools. New York, NY: Routledge.

Children's Defense Fund (1975). School suspensions: Are they helping children? A report. Cambridge, MA: Washington Research Project.

Cohen, T. H. (2013). Pretrial detention and misconduct in Federal District Courts, 1995-2010. Washington, D. C.: United States Department of Justice, Bureau of Justice Statistics.

Edwards, F. (2016). Saving children, controlling families: Punishment, redistribution and child protection. American Sociological Review, 81(3), 575-595.

Fabelo, T., Thompson, M. D., Plotkin, M., Carmichael, D., Marchbanks, M. P., \& Booth, E. A. (2011). Breaking schools' rules: A statewide study of how school discipline relates to students' success and juvenile justice involvement. New York, NY: Council of State Governments Justice Center. Retrieved from https://csgjusticecenter.org/wpcontent/uploads/2012/08/Breaking_Schools_Rules_Report_Final.pdf

Feeley, M. M., \& Simon, J. (1992). The new penology: Notes on the emerging strategy of corrections and its implications. Criminology, 34(4), 449-474.

Fenning, P., \& Rose, J. (2007). Overrepresentation of African American students in exclusionary discipline: The role of school policy. Urban Education, 42(6), 536-555. 
Fronius, T., Darling-Hammond, S., Persson, H., Guckenburg, S., Hurley, N., Petrosino, A. (2019). Restorative justice in U.S. schools: An updated research review. Woburn, MA: WestEd Justice and Prevention Research Center.

Gleicher, L., \& Delong, C. (n.d.). The cost of justice: The impact of criminal justice financial obligations on individuals and families. Chicago, IL: Illinois Criminal Justice Information Authority. Retrieved from http://www.icjia.state.il.us/articles/the-cost-ofjustice-the-impact-of-criminal-justice-financial-obligations-on-individuals-and-families

Gordon, N. (2018). Disproportionality in student discipline: Connecting policy to research. Washington, D. C.: Brookings Institution. Retrieved from: https://www.brookings.edu/research/disproportionality-in-student-discipline-connectingpolicy-to-research

Gray, L., Lewis, L., \& Ralph, J. (2015). Public school safety and discipline: 2013-14. Washington, D. C.: U. S. Department of Education, National Center for Education Statistics. Retrieved from https://nces.ed.gov/pubs2015/2015051.pdf

Gregory, A., Cornell, D., \& Fan, X. (2011). The relationship of school structure and support to suspension rates for black and white high school students. American Educational Research Journal, 48(4), 904-934.

Gregory, A., Huang, F. L., Anyon, Y., Greer, E., \& Downing, B. (2018). An examination of restorative interventions and racial equity in out-of-school suspensions. School Psychology Review, 47(2), 167-182.

Gregory, A., \& Weinstein, R. S. (2008). The discipline gap and African Americans: Defiance or cooperation in the high school classroom. Journal of School Psychology, 46(4), 455-475.

Hankin, A., Hertz, M., \& Simon, T. (2011). Impacts of metal detector use in schools: Insights from 15 years of research. Journal of School Health, 81(2), 100-106.

Holmes, S. (2017). Resisting arrest and racism - The crime of "disrespect." University of Missouri Kansas City Law Review, 85, 625-665. Retrieved from http://renapply.web.unc.edu/files/2017/08/2017-RESISTING-ARREST-ANDRACISM-THE-CRIME-OF-DISRESPECT-Scott-Holmes-1.pdf

Huang, F. L. (2016). Do black students misbehave more? Investigating the differential involvement hypothesis and out-of-school suspensions. Journal of Educational Research, 111(3), 284-294.

Huang, F. L., \& Cornell, D. G. (2017). Student attitudes and behaviors as explanations for the Black-White suspension gap. Children and Youth Services Review, 73, 298-308.

Hughes, E. C. (1945). Dilemmas and contradictions of status. American Journal of Sociology, 50(5), 353-359. 
Irby, D. J. (2014). Trouble at school: Understanding school discipline systems as nets of social control. Equity \& Excellence in Education, 47(4), 513-530.

Johnsen, S., Fitzpatrick, S., \& Watts, B. (2018). Homelessness and social control: A typology. Housing Studies.

Jordan, K., \& Freiburger, T. L. (2010). Examining the impact of race and ethnicity in the sentencing of juveniles in the adult court. Criminal Justice Policy Review, 21(2), 185201.

Kaeble, D. (2018). Probation and parole in the United States, 2016. Washington, D. C.: United States Department of Justice, Bureau of Justice Statistics. Retrieved from https://www.bjs.gov/content/pub/pdf/ppus16.pdf

Losen, D. J., Sun, W. L., \& Keith, M. A. (2017). Suspended education in Massachusetts: Using days of lost instruction due to suspension to evaluate our schools. Los Angeles, CA: The Civil Rights Project. Retrieved from http://www.schooldisciplinedata.org/ccrr/docs/suspended-education-web032317.pdf

Manglitz, E., Guy, T. C., \& Merriweather Hunn, L. R. (2006). Using counter narratives to construct a dialogue on race, positionality, and authority: A research tool. Presented at the 36th Annual SCUTREA Conference, Leeds, England: Trinity and All Saints College. Retrieved from http://www.leeds.ac.uk/educol/documents/155304.htm

Manning, P. K. (2001). Theorizing policing: The drama and myth of crime control in the NYPD. Theoretical Criminology, 5(3), 315-344.

McElrath, K. (2018). Medication-assisted treatment for opioid addiction in the United States: Critique and commentary. Substance Use and Misuse, 53(2), 334-343.

Moore, L. D., \& Padavic, I. (2010). Racial and ethnic disparities in girls' sentencing in the juvenile justice system. Feminist Criminology, 5(3), 263-285.

Morris, E. W., \& Perry, B. L. (2016). The punishment gap: School suspension and racial disparities in achievement. Social Problems, 63(1), 68-86.

Mowen, T., \& Brent, J. (2016). School discipline as a turning point: The cumulative effect of suspension on arrest. Journal of Research in Crime and Delinquency, 53(5), 628-653.

Nance, J. P. (2013). Random, suspicionless searches of public school students' belongings: A legal, empirical, and normative analysis. University of Colorado Law Review, 84(2), 367431.

National Center for Education Statistics. (2016). Percentage of public school students in grades 6 through 12 who had ever been suspended or expelled, by sex and racelethnicity: Selected years, 1993 through 2012 (School Safety and Discipline Survey and Parent and Family Involvement in Education Survey of the National Household Education Surveys 
Program No. Table 233.20). Washington, D. C.: United States Department of Education. Retrieved from https://nces.ed.gov/programs/digest/d16/tables/dt16_233.20.asp

Newburn, T., \& Jones, T. (2007). Symbolizing crime control: Reflections on zero tolerance. Theoretical Criminology, 11(2), 221-243.

Nicholson-Crotty, S., Birchmeier, Z., \& Valentine, D. (2009). Exploring the impact of school discipline on racial disproportion in the juvenile justice system. Social Science Quarterly, 90(4), 1004-1018.

Noltemeyer, A. L., Ward, R. M., \& Mcloughlin, C. S. (2015). Relationship between school suspension and student outcomes: A meta-analysis. School Psychology Review, 44(2), 224-240.

North Carolina State Legislature, North Carolina, Chapter $\S 115 C-390$, Article $27 \S$ (2011). Retrieved: https://www.ncleg.net/EnactedLegislation/Statutes/HTML/ByArticle/Chapter 115C/Article_27.html

Office for Civil Rights (2018). School climate and safety. 2015-16 Civil Rights Data Collection. Washington, D. C.: United States Department of Education. Retrieved https://www2.ed.gov/about/offices/list/ocr/docs/school-climate-and-safety.pdf

Peguero, A. A., Bondy, J. M., \& Shekarkhar, Z. (2016). Punishing Latina/o youth: School justice, fairness, order, dropping out, and gender disparities. Hispanic Journal of Behavioral Sciences, 39(1), 98-125.

Pfleger, R., \& Wiley, K. (2012). Colorado disciplinary practices, 2008-2010. Boulder, CO: National Education Policy Center. Retrieved from https://nepc.colorado.edu/sites/default/files/disciplinereport_0.pdf

Rabuy, B., \& Kopf, D. (2016). Detaining the poor. Northampton, MA: Prison Policy Initiative. Retrieved from https://www.prisonpolicy.org/reports/DetainingThePoor.pdf

Raffaele Mendez, L. M., \& Knoff, H. M. (2003). Who gets suspended from school and why: A demographic analysis of schools and disciplinary infractions in a large school district. Education and Treatment of Children, 26(1), 30-51.

Raufu, A. (2017). School-to-prison pipeline: Impact of school discipline on African American students. Journal of Education and Social Policy, 7(1), 47-53.

Rocque, M. (2010). Office discipline and student behavior: Does race matter? American Journal of Education, 116(4), 557-581.

Rocque, M., \& Snellings, Q. (2018). The new disciplinology: Research, theory, and remaining puzzles on the school-to-prison pipeline. Journal of Criminal Justice, 59(NovemberDecember), 3-11.

Rodriguez, N. (2003). The impact of "strikes" in sentencing decisions: Punishment for only some habitual offenders. Criminal Justice Policy Review, 14(1), 106-127. 
Saldaña, J. (2010). The coding manual for qualitative research. Thousand Oaks, California: Sage.

Schlesinger, T. (2011). The failure of race neutral policies: How mandatory terms and sentencing enhancements contribute to mass racialized incarceration. Crime and Delinquency, 57(1), 56-81.

Simon, J. (2007). Rise of the carceral state. Social Research, 74(2), 471-508.

Skiba, R. J., Arredondo, M. I., \& Williams, N. T. (2014a). More than a metaphor: The contribution of exclusionary discipline to a school-to-prison pipeline. Equity \& Excellence in Education, 47(4), 546-564.

Skiba, R. J., Chung, C., Trachok, M., Baker, T. L., Sheya, A., \& Hughes, R. L. (2014b). Parsing disciplinary disproportionality: Contributions of infraction, student, and school characteristics to out-of-school suspension and expulsion. American Educational Research Journal, 51(4), 640-670.

Skiba, R. J., Horner, R. H., Chung, C. G., Rausch, M. K., May, S. L., \& Tobin, T. (2011). Race is not neutral: A national investigation of African American and Latino disproportionality in school discipline. School Psychology Review, 40(1), 85-107.

Skiba, R. J., Michael, R. S., Nardo, A. C., \& Peterson, R. L. (2002). The color of discipline: Sources of racial and gender disproportionality in school punishment. Urban Review, 34(4), 317-327.

Steinberg, M. P. \& Lacoe, J. (2017). What do we know about school discipline reform? Assessing the alternatives to suspensions and expulsions. Education Next, 17(1), 44-52.

Theriot, M. T. (2009). School resource officers and the criminalization of student behavior. Journal of Criminal Justice, 37(3), 280-287.

United States Department of Education. (2015). Number of students receiving selected disciplinary actions in public elementary and secondary schools, by type of disciplinary action, disability status, sex, and race/ethnicity: 2011-12. Washington, D. C. Retrieved from https://nces.ed.gov/programs/digest/d15/tables/dt15_233.27.asp

United States Sentencing Commission. (2017). An overview of mandatory minimum penalties in the Federal criminal justice system. Washington, D. C.: United States Sentencing Commission. Retrieved from https://www.ussc.gov/sites/default/files/pdf/research-andpublications/research-publications/2017/20170711 Mand-Min.pdf

Vaznis, J. (2018). Boston schools agree to change policies on suspensions. Boston Globe, 17 November. Retrieved from: https://www.bostonglobe.com/metro/2018/11/16/bostonschools-agree-change-school-suspensions/WFHz9xwRjxZbJhCdN8ZrMP/story.html

Wacquant, L. (2001). Deadly symbiosis: When ghetto and prison meet and mesh. Punishment and Society, 3(1), 95-133. 
Warnick, B. R. (2007). Surveillance cameras in schools: An ethical analysis. Harvard Educational Review, 77(3), 317-343.

Welch, K. (2018). The effect of minority threat on risk management and the "new disciplinology" in schools. Journal of Criminal Justice , 59, (November-December), 1217.

Welch, K., \& Payne, A. A. (2012). Exclusionary school punishment: The effect of racial threat on expulsion and suspension. Youth Violence and Juvenile Justice, 10(2), 155-171.

Wiseman, S. R. (2014). Pretrial detention and the right to be monitored. Yale Law Journal, 123(5), 1344-1404.

Wood, J. L., Essien, I., \& Blevins, D. (2017). Black males in kindergarten: The effect of social skills on close and conflictual relationships with teachers. Journal of African American Males in Education, 8(2), 30-50.

Wood, J. L., \& Harris, F. (2016). Teaching boys and young men of color: A guidebook. San Diego, CA: Lawndale Hill.

Wrennall, L. (2010). Surveillance and child protection: De-mystifying the Trojan Horse. Surveillance and Society, 7(3/4), 304-324.

Wright, J. P., Morgan, M. A., Coyne, M. A., Beaver, K. M., \& Barnes, J. C. (2014). Prior problem behavior accounts for the racial gap in school suspensions. Journal of Criminal Justice, 42(3), 257-266.

Karen McEIrath is a Professor in the Department of Criminal Justice at Fayetteville State University. Her current research focuses on stigma and addiction, opioid use and treatment, and mixed-method approaches to school suspensions. She received her Ph.D. in Criminology from Florida State University.

Lori Guevara is an Associate Professor in the Department of Criminal Justice at Fayetteville State University. She earned her PhD from the University of Nebraska at Omaha and her research focuses on juvenile justice processing. She has published in Crime and Delinquency, Feminist Criminology, Youth Violence and Juvenile Justice: An International Journal, Race and Justice: An International Journal, and Journal of Ethnicity in Criminal Justice.

Zahra Shekarkhar is an Assistant Professor in the Department of Criminal Justice at Fayetteville State University. She earned her PhD from the University of Florida. Her research focuses on the educational and behavioral outcomes of youth across immigrant generation, gender, race, and ethnicity. She has published in journals such as Hispanic Journal of Behavioral Sciences, Education and Urban Society, the Journal of Immigrant \& Refugee Studies.

Joe M. Brown is an Associate Professor in the Department of Criminal Justice at Fayetteville State University. He received his Ph.D. in Juvenile Justice from Prairie View A\&M University. His research interests include Juvenile Sentencing, Disproportionate Minority Confinement, Race, Ethnicity, Gender and Waiver to Adult Court, and Reintegration. 